\title{
Penelitian Hadis Metode Syarah Pendekatan Kontemporer: Sebuah Panduan Skripsi, Tesis, dan Disertasi
}

\author{
Wahyudin Darmalaksana \\ UIN Sunan Gunung Djati Bandung; yudi_darma@uinsgd.ac.id \\ *Correspondence
}

Received: 2020-09-04; Accepted: 2020-09-15; Published: 2020-09-30

\begin{abstract}
The contemporary approach of sharah hadith has increased significantly in the Islamic higher education in Indonesia. However, guidance for academic research on this topic are very limited. The purpose of this research is to discuss the research of hadith with the contemporary approach of sharah methods to be used as a guide in the wriring of Undergraduate and MA theses and dissertations. This research employs a qualitative method through literature study with content analysis. The results of this study indicate the urgency of the sharah hadith for research, the significance of the preparation of writing proposal of the sharah hadith method, the search for a research model for sharah hadith as contemporary approaches using interdisciplinary, multidisciplinary, and transdisciplinary approaches. Furthermore, it is important to compile contemporary research guidelines for sharah hadith for undergraduate and MA theses as well as dissertations.
\end{abstract}

Key words: Research method; Contemporary approach; Sharah Hadith

\begin{abstract}
Abstrak: Syarah hadis pendekatan kontemporer telah berlangsung pesat di pendidikan tinggi Islam di Indonesia, namun panduan penelitian akademik belum ditemukan. Tujuan penelitian ini adalah membahas penelitian hadis metode syarah pendekatan kontemporer untuk panduan skripsi, tesis, dan disertasi. Metode penelitian ini menggunakan jenis kualitatif melalui studi pustaka dengan analisis isi. Hasil penelitian ini menunjukan urgensi syarah hadis, signifikansi penyusunan proposal metode syarah hadis, pencarian model penelitian syarah hadis pendekatan kontemporer interdisipliner, multidisipliner, dan transdisipliner, dan mendesaknya penyusunan panduan penelitian syarah hadis kontemporer untuk skripsi, tesis, dan disertasi.
\end{abstract}

Kata kunci: Metode penelitian; Pendekatan kontemporer; Syarah hadis.

\section{Pendahuluan}

Metode syarah dalam penelitian hadis bukan subjek yang asing. Metode ini cukup diminati kalangan akademisi Indonesia (Sagir, 2017). Misalnya, skripsi dari 37 judul angkatan 2015 dan 2016 mayoritas penelitian syarah 16 judul pada Jurusan Ilmu Hadis Fakultas Ushuluddin UIN Sunan Gunung Djati Bandung. Penelitian metode syarah hadis kontemporer bermuatan multidisipliner berkembang di pendidikan tinggi Islam di Indonesia (Taufik, 2020), tetapi panduan untuk skripsi, tesis, dan disertasi belum ditemukan.

Berberapa penelitain berkenaan dengan syarah hadis ditemukan. Menurut Muhammad Anshori, syarah sebagai penjelasan hadis, telah berlangsung sejak masa Nabi Saw., untuk menjawab problematika (Anshori, 2017). Bagi Egi Tanadi Taufik, syarah berupaya untuk menempatkan hadis sebagai core-value dialektika multidisipliner untuk menjawab problematika kontemporer dan 
kontekstual (Taufik, 2020). Menurut Nyayu Siti Zahrah, mulanya syarah hadis berlangsung secara lisan, kemudian berupa tulisan dengan metode tahlili (analitik), ijmali (global), dan muqarran (komparatif) disebabkan adanya hadis gharib dan seiring perkembangan ilmu pengetahuan muncul pendekatan baru, di antaranya hermeneutika dan pendekatan sosiologis, sehingga makna yang timbul lebih sesuai dengan konteks zaman (Zahrah, 2020). Dalam hal ini, Duwi Hariono memaparkan berbagai model dan aplikasi metodologis syarah hadis (Hariono, 2019). Selebihnya, Sulaemang menawarkan teknik interpretasi hadis bagi penerapannya dalam kitab-kitab syarah (Sulaemang, 2016). Elan Sumarna menunjukan syarah hadis dalam perspektif kritik dakhili (lingkar dalam hadis) dan khariji (lingkar luar hadis) untuk menuju pemaknaan hadis yang integritas (Sumarna, 2016). Penelitian syarah hadis berkembang dalam perjalanan sejarah, seperti penelitian kecenderungan syarah hadis di nusantara (Saifuddin, Dzikri, \& Noor'ainah, 2015), penelitian kitab syarah dalam tradisi intelektual pesantren (Suwarjin, 2018), penelitian metode syarah dalam kitab tertentu (Qomarullah, 2020), dan penelitian syarah hadis kontemporer (HS \& Faizah, 2020). Mohammad Mohtador, secara detail menunjukan sejarah perkembangan metode pendekatan syarah hadis (Muhtador, 2016). Disambung oleh Akhmad Sagir yang secara komprehensif menjelaskan perkembangan syarah hadis dalam tradisi keilmuan Islam (Sagir, 2017). Benny Afwadzi menekankan urgensi membangun integrasi ilmu-ilmu sosial dan hadis Nabi (Afwadzi, 2016). Muhammad Alfatih Suryadilaga memberikan gambaran tentang urgensi pembacaan hadis dalam perspektif antropologi (Suryadilaga, 2017). Darrotul Jannah memberikan struktur penelitian hadis dimulai dari takhrij hadis hingga syarah hadis (Jannah, 2017). Yunita Kurniati, lebih menghendaki penguatan metode syarah klasik yang lebih diakui otoritasnya dibandingkan pendekatan syarah hadis kontemporer (Kurniati, 2020).

Sejumlah penelitian terdahulu berperan signifikan untuk menyusun kerangka berpikir. Para peneliti dari kalangan peminat dan ahli hadis sepakat berkenaan dengan otoritas keilmuan metode syarah kalasik dalam pendekatan tahlili, ijmali, dan muqarran (Zahrah, 2020). Disepakati pula tentang konteks penelitian syarah hadis yang menyangkut kritik dakhili (lingkar dalam hadis) dan khariji (lingkar luar hadis) yang berorientasi untuk menemukan pemaknaan hadis yang integritas (Sumarna, 2016). Disepakti pula struktur penelitian syarah hadis terlebih dahulu dimulai dengan penelitian takhrij hadis untuk menguji otentisitas hadis (Jannah, 2017). Beberapa kalangan menganjurkan pendekatan baru, berupa pendekatan kontemporer, seperti hermeneutika dan sosiologi (Zahrah, 2020) serta antropologi (Suryadilaga, 2017). Bahkan, ada kalangan yang menyuarakan sisi penting membangun integrasi ilmu-ilmu sosial dan hadis Nabi (Afwadzi, 2016). Kenyataannya, syarah hadis mengalami perkembangan signifikan dalam tradisi keilmuan Islam (Sagir, 2017), sehingga menghasilkan ragam model dan aplikasi metodologis syarah hadis (Hariono, 2019), ragam teknik interpretasi hadis dalam kitab-kitab syarah hadis (Sulaemang, 2016), dan berkembangnya metode pendekatan syarah hadis di dunia Islam (Muhtador, 2016). Beberapa kalangan menghendaki penerapan metode syarah hadis kontemporer diarahkan untuk mampu menjawab problematika zaman (Anshori, 2017). Kalangan ini menghendaki metode syarah hadis menjadi nilai inti multidisipliner untuk menjawab berbagai problematika kontemporer dan kontekstual (Taufik, 2020). Disebut-sebut bahwa pada periode modern, syarah hadis mulai menerapkan ilmu-ilmu sosial-humaniora ataupun ilmu sains modern (Anshori, 2017). Ternyata, begitu kompleks metode dalam memahami hadis berkenaan dengan khazanah tradisional dan khazanah kontemporer (Burhanuddin, 2018).

Berdasarkan paparan di atas, formula penelitian dapat dirumuskan, yaitu rumusan masalah, pertanyaan penelitian, dan tujuan penelitian (Darmalaksana, 2020c). Rumusan masalah penelitian ini adalah, terdapat penelitian hadis metode syarah pendekatan kontemporer. Pertanyaannya ialah, bagaimana penelitian hadis metode syarah pendekatan kontemporer untuk panduan skripsi, tesis, dan disertasi. Tujuan penelitian ini, yaitu membahas penelitian hadis metode syarah pendekatan kontemporer sebagai panduan skripsi, tesis, dan disertasi. Metode penelitian ini menggunakan jenis kualitatif melalui studi pustaka dengan analisis isi (Darmalaksana, 2020e). Hasil penelitian ini diharapkan memiliki implikasi manfaat khususnya bagi akademisi peminat metode syarah hadis dalam penyusunan skripsi, tesis, dan disertasi. 


\section{Hasil Penelitian}

\section{Urgensi Syarah hadis}

Syarah hadis merupakan kekayaan khazanah Islam yang terus mengalami perkembangan. Kata "syarah" dalam bahasa Arab berarti menjelaskan, menafsirkan, dan membeberkan (Muhtador, 2016). Kata syarah berkenaan dengan hadis Nabi, adalah usaha menjelaskan makna yang terdapat dibalik teks hadis (Muhtador, 2016). Sebagaimana Al-Qur'an yang tidak bisa dipahami tanpa tafsir, demikian juga hadis yang harus dipahami dengan syarah atau penjelasan. Dalam tradisi Islam, penjelasan untuk Al-Qur'an disebut tafsir, sedangkan penjelasan untuk hadis disebut syarah (Anshori, 2017).

Tradisi syarah hadis telah dimulai sejak masa Nabi, meskipun tidak seperti penelitian syarah yang dikenal di era kontemporer, di mana masing-masing periode memiliki karakteristik tersendiri, yakni masa klasik masih terkonsentrasi pada pembukuan hadis, penjelasan makna kata yang gharib, dan munculnya embrio syarah hadis (Anshori, 2017). Abad pertengahan mulai dilakukan pembukuan syarah hadis, tetapi lebih didominasi kitab-kitab dalam kategori al-Kutub al-Sittah. Periode modern, tradisi syarah hadis sudah berkembang dengan pesat, tetapi masih memiliki kemiripan dengan periode abad pertengahan karena masih didominasi al-Kutub al-Sittah, dan kebanyakan sarjana-sarjana muslim hanya mengulangi penjelasan ulama-ulama sebelumnya (Anshori, 2017). Akan tetapi, satu hal yang membedakan dengan dua periode sebelumnya, periode modern mulai menjelaskan hadis dengan ilmu-ilmu sosial-humaniora ataupun ilmu sains modern era kontemporer (Anshori, 2017).

Syarah hadis masa klasik ditemukan beberapa metode utama, yakni ijmali (global), tahlili (analitik), dan muqaran (komparatif). Pertama, metode ijmali berperan menjelaskan atau menerangkan hadis-hadis sesuai dengan urutan dalam kitab hadis yang ada dalam al-Kutub al-Sittah secara ringkas, tetapi dapat merepresentasikan makna literal hadis dengan bahasa yang mudah dimengerti dan dipahami. Kitab metode ijmali ialah syarh al-Syuyuti li Sunan al-Nasa'i karya Jalaluddin as-Syuyuti dan Qut al-Mugtazi 'ala Jami' al-Tirmidzi karya jalal al-Din al-Syuyuti (Muhtador, 2016).

Kedua, metode tahlili berperan mengurai, menganalisis, dan menjelaskan makna yang terkandung dalam hadis dengan memaparkan substansi yang terkandung di dalamnya dengan keahlian dan kecendrungan subjek pensyarah. Metode ini memiliki kesamaan dengan ijmali dalam sistematika penyusunan syarah. Metode tahlili mengungkap berbagai hal berkenaan dengan substansi dan kandungan hadis. Mulai dari bahasa, korelasi, dan asbab al-wurud (Muin, 2015). Dalam metode ini dijelaskan makna mufradat (kosa kata), makna kalimat, dan munasabah (hubungan) dengan hadis lain. Juga diuraikan pemahaman pada masa sahabat, tabi'in, dan ulama terdahulu. Akan tetapi, pembahasan tahlili bersifat parsial sehingga melahirkan syarah yang subjektif. Contoh kitab metode tahlili adalah Fath al Bari bi Syarhi Shahih Bukhari karya Ibnu Hajar al-Asqalani dan Ibanatul Ahkam bi Syarhi Buluqhul Maram karya Syamsuddin Muhamad Bin Yusuf Bin Ali al-Kirmani (Muhtador, 2016).

Ketiga, metode muqaran (komparatif) berperan mengkaji hadis dengan membandingkan hadis yang memiliki redaksi yang sama atau mirip dalam kasus yang sama atau memiliki redaksi yang berbeda dalam kasus yang sama, atau membandingkan berbagai pendapat ulama dalam mensyarah hadis. Cotoh kitab metode ini adalah Shahih Muslim bi al-Syarh Nawawi karya Imam Nawawi dan Umdah al-Qari Syarh Imam Bukhari, karya Badr al-Din Abu Muhammad Mahmud al-'Aini (Muhtador, 2016).

Syarah hadis sejatinya diarahkan untuk memahami karya-karya ulama yang berusaha memberikan syarah terhadap kitab-kitab sebelumnya, sebab beberapa kitab yang berisi kaidah-kaidah ilmu hadis tidak dapat dipahami secara mudah oleh berbagai kalangan sehingga dibutuhkan penelitian terhadap kitab-kitab syarah (Farida, 2020). Metode syarah hadis pada kenyataannya terus mengalami perkembangan (Sagir, 2017), hal ini dilihat dari hadis dan sejarah perkembangannya di dunia Islam (Andariati, 2020), tidak terkecuali perkembangan hadis di Indonesia (Khaeruman, 2017). Sehingga 
perkembangan hadis melahirkan ragam metode sayarah (Hariono, 2019) dan sejumlah teknik interpretasi syarah hadis (Sulaemang, 2016).

Sejarah perkembangan metode dan pendekatan syarah hadis (Muhtador, 2016) mencatat timbulnya sejumlah metode mutakhir kontemporer yang interdisipliner (Rohmatika, 2019). Urgensi penelitian metode syarah hadis dengan perkembangan kontemporer disebut-sebut berperan untuk mengatasi berbagai problematikan umat secara kontekstual (Taufik, 2020).

\section{Proposal Penelitian Metode Syarah Hadis}

Suatu penelitian pasti diawali dengan penyusunan proposal penelitian. Hal ini merupakan bangunan yang saling terkait mencakup latarbelakang masalah, rumusan masalah, pertanyaan penelitian, tujuan penelitian, manfaat penelitian, tinjauan pustaka, kerangka berpikir, metode penelitian, dan sistematika penulisan (Darmalaksana, 2020b). Apakah penelitian syarah hadis untuk penelitian skripsi harus dilatarbelakangi oleh adanya problem di masyarakat. Jawaban atas pertanyaan ini adalah, tidak selalu penelitian skripsi harus dilatarbelakangi problem. Sebab, penelitian, terlebih skripsi, tidak sepenuhnya dimaksudkan untuk mengatasi problem (Darmalaksana, 2020b).

Penelitian metode syarah hadis, sebagaimana penelitian lainnya, bisa dilaksanakan dengan adanya fokus penelitian atau fokus studi (Sherman \& Webb, 1988). Fokus studi merupakan bagian dari tema, sedangkan tema adalah bagian dari topik, dan topik ialah bagian dari subjek. Subjek penelitian adalah lingkup keilmuan bidang studi, yang dalam hal ini hadis dan ilmu hadis (Ad., 2005). Apabila dilihat dari penelitian dasar dan penelitian terapan (Bentley, Gulbrandsen, \& Kyvik, 2015), maka hadis merupakan rumpun materi dasar. Penelitian materi dasar (basic) tidak selalu mesti dilatarbelakangi adanya problem, berbeda dengan penelitian terapan (applied) di bidang sains dan teknologi yang menuntut adanya problem untuk pemecahan masalah. Penelitian materi dasar syarah hadis cukup dengan adanya fokus studi (Darmalaksana, 2020b).

Bagian rumusan masalah, pertanyaan penelitian, dan tujuan penelitian dirangkum ke dalam formula penelitian (Darmalaksana, 2020b). Rumusan masalah diawali kata "terdapat." Misalnya, rumusan masalah terdapat nilai inti iman menurut hadis. Pertanyaannya adalah bagaimana nilai inti iman menurut hadis. Tujuan penelitiannya yaitu menjelaskan nilai inti iman menurut hadis. Himpunan rumusan masalah, pertanyaan penelitian, dan tujuan penelitian ini yang disebut formula penelitian (Darmalaksana, 2020b).

Manfaat penelitian mesti sudah dapat ditentukan berdasarkan tujuan penelitian. Hal ini dengan asumsi bahwa suatu tujuan penelitian pasti berdampak manfaat, bergantung sasaran penerima manfaat. Manfaat penelitian lebih terasa lagi nanti pada bagian kesimpulan. Sebuah penelitian pasti nanti menghendaki ditariknya suatu kesimpulan. Manfaat penelitian dapat diukur dari kesimpulan penelitian (Darmalaksana, 2020b).

Tinjauan pustaka berperan penting dalam banyak hal. Pertama, mengetahui penelitian terdahulu dengan cara penelusuran pada repositori hasil-hasil penelitian. Penelusuran referensi bukan perkara yang sulit di era digital, sebab telah tersedia berbagai himpunan data besar (big data), baik e-books maupun e-journals (Darmalaksana, 2020a). Penghimpunan referensi pun dengan mudah bisa digunakan aplikasi references (Darmalaksana, 2020g). Kedua, tinjauan pusatka bermanfaat untuk menghimpun teori yang dibutuhkan ketika menyusun kerangka berpikir. Ketiga, tinjauan pustaka menjadi landasan apakah menolak, mendukung, mensintesis, dan mengembangkan penelitian terdahulu. Keempat, tinjauan pustaka berfungsi untuk menegaskan posisi penulis di antara penelitian sebelumnya dari sisi persamaan dan perbedaannya. Tentu saja masih panjang bila dilanjutkan peran dan kegunaan tinjauan pustaka (Cawelti, 1969).

Kerangka berpikir berperan untuk merangkai teori yang menjadi landasan teoritis penelitian. Kerangka berpikir pada dasarnya merupakan miniatur jawaban pertanyaan penelitian. Kerangka berpikir berfungsi menjelaskan secara garis besar alur logis berjalannya sebuah penelitian. Kerangka berpikir sekaligus juga sebagai peta konsep untuk tiba pada tujuan penelitian. Dengan demikian, kerangka berpikir adalah miniatur jawaban penelitian, alur logis berjalannya penelitian, dan peta konsep untuk tiba pada tujuan penelitian. Akan tetapi, teori yang dirangkai pada kerangka teori akan 
bergantung pada rujukan yang ditemukan ketika melakukan tinjauan pustaka. Peneliti bisa menyusun kerangka berpikir apa pun, tetapi hal tersebut tidak mungkin dilakukan tanpa dukungan referensi yang diperoleh ketika melakukan tinjauan pustaka. Jelaslah bahwa tinjauan pustaka berperan signifikan untuk menghimpun teori bagi kepentingkan menyusun kerangka berpikir (Darmalaksana, 2020b).

Metode penelitian syarah hadis memiliki redaksi yang baku. Metode penelitian sendiri adalah skenario tentang tahapan pelaksanaan penelitian, sejak pra-penelitian, pelaksanaan penelitian, dan penulisan ilmiah hasil penelitian (Darmalaksana, 2020b). Redaksi metode penelitian syarah hadis, yakni penelitian ini menggunakan jenis kualitatif melalui studi pustaka dengan analisis syarah hadis (Darmalaksana, 2020e). Apabila digunakan pendekatan tertentu, maka redaksi metode penelitian syarah hadis, yakni penelitian ini menggunakan jenis kualitatif melalui studi pustaka dengan metode syarah hadis pendekatan, misalnya, hermeneutika, sosiologi, dan antropologi (Suryadilaga, 2017). Disebutkan pula tahapan pelaksanaan penelitian, sejak pengumpulan referensi, klasifikasi, penampilan (display) data, abstraksi data, dan interpretasi serta analisis data sampai menghasilkan kesimpulan (Darmalaksana, 2020b).

Sistematika penulisan hasil penelitian disusun dari kerangka berpikir (Darmalaksana, 2020b). Kerangka berpikir merupakan miniatur jawaban pertanyaan penelitian. Sistematika penulisan merupakan uraian tentang jawaban pertanyaan penelitian. Kerangka berpikir terdiri atas sejumlah peragraf di mana masing-masing paragraf merupakan miniatur jawaban pertanyaan penelitian untuk disusun ke dalam sistematika penulisan, sejak pendahuluan, teori umum, hasil dan pembahasan penelitian, dan hingga kesimpulan (Darmalaksana, 2020b).

\section{Syarah Hadis Pendekatan Kontemporer}

Penelitian dilaksanakan untuk menjawab pertanyaan penelitian selaras dengan tujuan penelitian. Secara garis besar, jawaban penelitian mencakup hasil dan pembahasan. Suatu fokus penelitian biasanya dibangun dengan satu pertanyaan penelitian utama tunggal, sebagaimana contoh terdahulu, yakni bagaimana nilai inti iman menurut hadis. Namun, satu pertanyaan penelitian utama tunggal pada dasarnya dapat diurai menjadi beberapa pertanyaan terperinci (Darmalaksana, 2020c). Mengurai pertanyaan menjadi rinci dimaksudkan untuk menstrukturkan penulisan hasil dan pembahasan penelitian. Uraian pertanyaan penelitian secara rinci, misalnya, bagaimana pengertian nilai dan iman, bagaimana hadis tentang iman, dan bagaimana nilai inti iman menurut hadis. Bagian hasil dan pembahasan merupakan jawaban seluruh pertanyaan penelitian selaras dengan tujuan penelitian.

Bagian hasil mula-mula menampilkan teori yang digunakan dalam penelitian. Teori penelitian yang digunakan secara sederhana pada dasarnya telah ditampilkan pada bagian kerangka berpikir dalam proposal penelitian. Teori ini pun biasanya secara luas dan mendalam disajikan dalam bab tersendiri. Apabila teori telah disajikan, maka giliran menyajikan bagian hasil penelitian dalam arti yang sebenarnya (Darmalaksana, 2020d).

Struktur penampilan hasil penelitian metode syarah hadis dapat diurutkan ke dalam tiga bagian. Pertama, penyajian teks hadis berkenaan dengan topik yang akan disyarah. Hendaknya teks hadis subjek syarah merupakan matan hadis yang telah dilakukan kritik takhrij hadis (Jannah, 2017). Sebab, hal ini merupakan struktur penelitian hadis, tentang sanad dan matan hadis, yakni dimulai dengan takhrij hadis dan dilanjutkan dengan syarah hadis (Soetari, 2015). Akan tetapi, takhrij hadis dan sekaligus syarah hadis pasti menghasilkan lembar halaman yang tebal, bila hal ini diterapkan bagi penelitian skripsi. Sehingga hal ini dibutuhkan dua penelitian terpisah, yakni penelitian takhrij hadis dan penelitian syarah hadis. Meskipun penelitian takhrij hadis biasanya telah dicantumkan pula syarah hadis sederhana. Walaupun penelitian syarah hadis pun dituntut takhrij hadis secara sederhana. Namun, syarah hadis semestinya dilakukan terhadap matan hadis dengan terlebih dahulu telah dilakukan kritik takhrij hadis (Jannah, 2017). Kedua, pelaksanaan syarah hadis, setelah teks hadis dan sekaligus terjemah matan hadis disajikan, tiba gilirannya melaksanakan syarah hadis. Pelaksanaan syarah hadis bergantung metode syarah hadis yang digunakan dari berbagai metode syarah hadis yang populer, seperti ijmali, tahlili, dan muqaran (Hariono, 2019). 
Metode hendaknya disebutkan di bagian metode penelitian di bagian proposal penelitian. Apakah metode ijmali, tahlili, dan muqaran, dan ataukah gabungan seluruhnya. Adapun redaksi metode penelitian yakni penelitian ini menggunakan jenis kualitatif melalui studi pustaka dengan metode syarah analisis ijmali, tahlili, dan muqaran. Semua ini merupakan metode syarah hadis klasik yang dibedakan dengan metode syarah hadis kontemporer (Kurniati, 2020). Diakui bahwa syarah hadis mengalami perkembangan yang cukup pesat, sejak masa klasik hingga masa kontemporer (Sagir, 2017).

Paparan di atas, terkait dengan penyajian hasil penelitian, telah menunjukan dua hal, yakni pertama, menampilkan teks hadis dan terjemah, dan kedua, melakukan syarah hadis melalui metode ijmali, tahlili, dan muqaran. Selanjutnya, ketiga, tiba gilirannya untuk secara khusus melakukan pembahasan (discussion) hasil penelitian. Beberapa langkah bisa dilakukan pada bagian pembahasan hasil penelitian (Darmalaksana, 2020d). Pertama, mendiskusikan hasil penelitian dengan teori yang digunakan dalam penelitian. Sebuah penelitian, sebagaimana dipaparkan terdahulu, biasanya menempatkan teori pada bagian kerangka berpikir dan tinjauan umum teoritis (Darmalaksana, 2020b). Kedua, temuan penelitian dapat dibandingkan dengan temuan penelitian lain. Temuan hasil penelitian terdahulu biasanya ditempatkan pada bagian tinjauan pustaka (Darmalaksana, 2020b). Ketiga, melakukan analisis dengan pendekatan yang digunakan dalam penelitian di antaranya pendekatan kontemporer interdisipliner (Darmalaksana, 2020d).

Penelitian hadis metode syarah hadis dengan pendekatan kontemporer interdisipliner berarti menghendaki hasil penelitian syarah hadis dianalisis dengan pendekatan ilmu-ilmu lain yang serumpun dan relevan (Rohmatika, 2019). Selain pendekatan interdisipliner, ada pula yang disebut pendekatan multidisipliner, yaitu pendekatan dalam membahas hasil penelitian dengan menggunakan tinjauan berbagai sudut pandang ilmu, meskipun tidak serumpun (Rohmatika, 2019). Bahkan, ada yang disebut dengan pendekatan transdisipliner, yakni pendekatan dalam membahas hasil penelitian untuk mengintegrasikan yang multidisipliner secara lintas ilmu (Sudikan, 2015). Dalam pendekatan interdisipliner yang diperlukan adalah bagaimana menciptakan sarjana-sarjana yang memiliki keahlian di bidang keilmuan Islam, tetapi juga memiliki kemampuan dalam menganalisis realitas sosial (Mujtaba, 2015).

Ulama di masa klasik pada dasarnya telah melaksanakan syarah hadis dengan pendekatan interdisipiner (Santosa, 2016). Hal ini ditunjukan dengan adanya sejumlah teknik interpretasi hadis dalam kitab syarah hadis (Sulaemang, 2016). Di antaranya syarah hadis dengan perspektif kritik dakhili (lingkar dalam hadis) dan khariji (lingkar luar hadis) untuk menghasilkan pemaknaan hasdis yang integritas (Sumarna, 2016). Sehingga ditemukan metode syarah hadis dalam berbagai model serta aplikasi metodologis (Hariono, 2019). Temuan ini tidak terlepas dari hasil pelacakan terhadap sejarah perkembangan metode serta pendekatan syarah hadis (Muhtador, 2016). Dengan demikian, ulama terdahulu pada dasarnya telah melakukan syarah hadis secara interdisipliner dengan bidang fiqih, teologi, tasawuf, dan lain-lain. Namun, hal ini masih dalam pandangan yang terbatas berbeda dengan era kontemporer yang didorong dengan pesatnya berbagai ilmu pengetahuan. Pada era kontemporer sekarang ini tengah berlangsung upaya membangun integrasi ilmu-ilmu sosial dan hadis Nabi (Afwadzi, 2016).

Beberapa hal penting diperhatikan dalam penelitian kontemporer interdisipliner. Subjek penelitian memainkan fungsi utama dalam penelitian. Subjek penelitaian bidang hadis mecakup hadis dan ilmu hadis (Ad., 1994). Dalam penelitian interdisipliner bisa saja penelitian terbawa arus disiplin ilmu lain. Misalnya, kompetensi peneliti pada dasarnya merupakan bidang hadis, tetapi penelitiannya kental dengan subjek fiqih (Hosen \& Musyafiq, 2019). Ini merupakan akibat hegemoni fiqih pada ilmu hadis (Rodliyana, 2012). Kenyataan ini sering terjadi dalam penelitian kontemporer interdisipliner dan terlebih dalam penelitian multidisipliner dan transdisipliner. Dalam penelitian transdisipliner dibutuhkan kolaborasi kompetensi keilmuan antara bidang hadis dan bidang ilmu lain (Afwadzi, 2016). Sebab, bidang masing-masing ilmu memiliki subjek dan kedalamannya tersendiri (Nugraha, 2020). 
Pada tataran ini terasa sekali pentingnya penelitian kolaboratif sebagaimana sedang digalakan di pendidikan tinggi Islam (Amal, 2019.). Sebuah penelitian bukan keluasan yang paling utama, melainkan kedalaman subjek penelitian bidang ilmu. Terlebih lagi penting diperhatikan untuk tidak terbawa arus oleh bidang ilmu yang bukan merupakan kompetensi keahlian peneliti. Berkenaan dengan hal ini, sebagaimana ditegaskan terdahulu, terkadang masih ditemukan kasus skripsi bidang hadis tetapi secara tegas tampak mengusung bidang fiqih (Rodliyana, 2012) atau bidang kesehatan, farmasi dan lain-lain (Dalil, 2017). Dengan demikian, penting mencirikan subjek penelitian bidang keilmuan dan keahlian spesifik untuk bidang hadis dan ilmu hadis. Khusus, berkenaan dengan penelitian syarah hadis pendekatan interdisipliner, supaya diperhatikan kedalaman bidang keilmuan bidang hadis, maka penting dirumuskan panduan sejak penyusunan proposal penelitian model interdisipliner (Darmalaksana, 2018).

Ada hal yang perlu dikonfirmasi pada bagian hasil dan pembahasan penelitian. Pertama, apakah seluruh pertanyaan penelitian telah terjawab. Kedua, apakah hasil dan pembahasan penelitian telah tiba sampai pada tujuan penelitian. Ketiga, apakah bagian hasil dan pembahasan telah terhindari dari hal-hal yang tidak diperlukan. Tiga poin inilah yang penting untuk dikonfirmasi pada bagian hasil dan pembahasan penelitian (Darmalaksana, 2020d).

Kesimpulan penelitian disajikan setelah hasil dan pembahasan penelitian. Kesimpulan bukan pengulangan bagian pembahasan, melainkan natijah dari penelitian yang telah dilaksanakan (Darmalaksana, 2020d). Pada bagian kesimpulan disebutkan implikasi bagi penerima manfaat. Suatu penelitian tentu tidak mungkin mencakup keseluruan tema pembahasan, pasti ada hal-hal yang merupakan kekurangan. Dalam hal ini, penting dikemukakan keterbatasan penelitian, sehingga diperlukan penelitian lebih lanjut untuk melengkapi kekurangan. Pada bagian kesimpulan dikemukakan pula rekomendasi, khususnya bagi pengampu kebijakan untuk realisasi hasil penelitian (Darmalaksana, 2020d). Tegaslah penelitian kontemporer dalam syarah hadis syarat dengan berbagai ketentuan (Sumarna, 2016).

\section{Syarah Hadis Skripsi, Tesis, dan Disertasi}

Syarah hadis dapat diterapkan untuk skripsi jenjang sarjana, tesis jenjang magister, dan disertasi jenjang doktor. Diketahui bahwa akademisi Jurusan Ilmu Hadis jejang sarjana diarahkan untuk menjadi asisten peneliti hadis dan sosial keagamaan (Tim Penyusun, 2018a). Sedangkan akademisi Jurusan Ilmu Hadis jejang magister dan doktor diarahkan untuk menjadi peneliti (Tim Penyusun, 2018b).

Akademisi lulusan sarjana diarahkan sebagai asisten peneliti yang mampu melaksanakan penelitian dan pengkajian di bidang hadis dan pengembangan ilmu hadis, serta mampu menerjemahkan kandungan hadis untuk pengembangan ajaran Islam (Tim Penyusun, 2018a). Akademisi lulusan magister diarahkan sebagai peneliti yang memiliki kemampuan merencanakan, melaksanakan, dan mempublikasikan serta mengelola hasil penelitian dalam bidang ilmu hadis sesuai dengan perkembangan ilmu pengetahuan mutakhir (Tim Penyusun, 2018b). Akademisi lulusan doktor diarahkan sebagai peneliti yang mampu mengembangkan, mengelola, dan memimpin penelitian dalam bidang ilmu hadis dengan pendekatan interdisipliner, multidisipliner dan transdisipliner serta mendapatkan pengakuan secara nasional dan internasional (Tim Penyusun, 2018b).

Berdasarkan arah kebijakan, penelitian syarah hadis untuk jenjang sarjana, yang diarahkan untuk menjadi asisten peneliti, pada dasarnya belum dibebankan untuk penerapan kontemporer interdisipliner. Akademisi ulusan sarjana masih fokus diarahkan untuk mampu melaksanakan penelitian bidang hadis, pengembangan ilmu hadis, dan mampu menerjemahkan kandungan hadis (Tim Penyusun, 2018a). Artinya, akademisi jenjang sarjana lebih diarahkan untuk penguatan metodologi keilmuan syarah hadis klasik meliputi ijmali, tahlili, dan muqaran (Kurniati, 2020). Baru pada jenjang magister mulai diarahkan memiliki kemampuan mengelola hasil penelitian bidang ilmu hadis sesuai dengan perkembangan ilmu pengetahuan mutakhir (Tim Penyusun, 2018b). Terlebih pada jenjang doktor secara tegas diarahkan untuk mampu memimpin penelitian dalam bidang ilmu hadis 
dengan pendekatan kontemporer interdisipliner, multidisipliner dan transdisipliner (Tim Penyusun, 2018b).

Penelitian syarah hadis hendaknya memiliki rencana implementasi di pendidikan tinggi Islam (Darmalaksana, 2020f). Arah kebijakan telah menetapkan agenda riset keagamaan nasional (Tim Penyusun, 2018c). Pertama, tahun 2018-2023 meliputi penguatan riset dasar dan publikasi di jurnal nasional, internasional, dan perolehan hak cipta. Kedua, tahun 2023-2028 meliputi penguatan riset terapan dan publikasi di jurnal nasional, internasional, dan perolehan hak cipta dan hak paten. Agenda ini dapat didistribusi pada jenjang sarjana, magister, dan doktor (Tim Penyusun, 2018c).

Syarah hadis pada jenjang sarjana cukup diarahkan untuk menjelaskan kandungan hadis (Tim Penyusun, 2018a). Syarah hadis pada jenjang magister diarahkan untuk menganalisis hadis dengan pendekatan pengetahuan mutakhir (Tim Penyusun, 2018b). Syarah hadis pada jenjang doktor diarahkan untuk menerapkan pendekatan kontemporer interdisipliner, multidisipliner dan transdisipliner (Tim Penyusun, 2018b). Telah ditegaskan bahwa penelitian syarah hadis jenjang sarjana tidak selalu mesti dilatarbelakangi problem (Darmalaksana, 2020b). Akan tetapi, skripsi lebih diarahkan untuk melaksanakan penelitian yang baik dengan menggunakan merode syarah pendekatan ijmali, tahlili, dan muqaran (Kurniati, 2020). Termasuk penggunaan sebab wurud hadis dalam penelitian syarah hadis (Muin, 2015). Apabila tanpa panduan penelitian yang memadai, maka pendekatan syarah hadis kontemporer interdisipliner pada jejang sarjana dapat berkonsekuensi memalingkan subjek penelitian pada bidang keilmuan lain yang bukan bidang keahliannya, seperti berlangsungnya hegemoni fiqih sejak sekian lama (Rodliyana, 2012). Memang fiqih dan hadis seakan romantisme tidak bisa dilepaskan (Arifin, 2014), namun tetap mesti terdapat pembeda antara kompetensi ahli hadis dan ahli hukum Islam (Hosen \& Musyafiq, t.t.).

Pada prinsipnya penelitian skripsi tidak masalah memulai penelitian metode syarah pendekatan kontemporer interdisipliner. Hanya saja beberapa hal penting untuk diperhatikan. Pertama, penelitian tetap berpijak pada subjek penelitian bidang ilmu hadis tanpa bergeser pada subjek penelitian bidang kompetensi lain. Kedua, penelitian skripsi kontemporer interdisipliner tidak selalu dilatarbelakangi problem untuk penyelesaian masalah, tetapi mereka cukup menjelaskan subjek, topik, dan tema penelitian secara terfokus. Ketiga, penelitian skripsi tidak selalu diarahkan untuk menemukan fokus menarik, karena aturan penulisan skripsi yang paling penting yaitu menulis dengan baik dan benar sesuai panduan yang telah disedikan pendidikan tinggi. Keempat, penelitan bukan dilihat dari keluasan melainkan dari kedalaman. Kelima, pendekatan kontemporer interdisipliner dalam syarah hadis diarahkan sebagai penguatan analisis metode syarah hadis dengan mengambil salah satu disiplin ilmu lain yang serumpun dan relevan. Berkenaan dengan hal ini, misalnya penlitian interdisipliner dengan khazanah tasawuf (Raharusun, 2016) dan misal yang lain penelitian matan hadis misoginis (Dadah, 2018). Tentu, ketentuan mengacu pada panduan penelitian merupakan hal yang tidak dapat diabaikan (Darmalaksana, 2018).

Kenyataannya penelitian kontemporer interdisipliner syarah hadis telah merambah skripsi. Karena itu, arah kebijakan tesis dapat berfokus pada syarah hadis multidisipliner, dan disertasi berfokus pada syarah hadis transdisipliner. Syarah hadis kontemporer interdisipliner skripsi cukup menerapkan jenis penelitian kualitatif melalui studi pustaka dan bisa pula sekaligus studi lapangan (Darmalaksana, 2020e). Jenis penelitian kuantitatif (Prsetyo \& Jannah, 2019) pada dasarnya tidak direkomendasikan untuk syarah hadis penelitian skripsi. Sebab, bidang hadis merupakan materi ilmu dasar. Kecuali bila jenjang sarjana memiliki kemampuan menerapkan jenis penelitian kuantitatif (Yusuf, 2016). Adapun arah kebijakan bagi tesis dan disertasi memungkinkan merambah pada jenis penelitian kuantitatif (Mulyadi, 2011). Tentu tetap berpijak pada prinsip dasar bahwa bidang hadis dan ilmu hadis bukanlah materi terapan, melainkan materi ilmu dasar (Nurgiyantoro \& Gunawan, 2004).

Materi dasar syarah hadis kontemporer interdisipliner skripsi berperan menjelaskan kandungan hadis (Tim Penyusun, 2018a). Syarah hadis multidisipliner tesis berperan menerapkan analisis dengan pendekatan mutakhir dan syarah hadis transdisipliner disertasi berperan menemukan teori baru atau postulat baru (Tim Penyusun, 2018b). Meskipun pada implementasinya syarah hadis kontemporer transdisipliner pasti dibutuhkan kolaborasi dengan akademisi bidang ilmu terapan dalam lingkup 
sains dan teknologi (Afwadzi, 2016). Memang integrasi ilmu pasti merupakan subjek yang masih pelik dalam penelitian syarah hadis (Firdaus \& Suryadilaga, 2019). Namun, integrasi ilmu merupakan mandat (Tim Penyusun, 2019) yang mesti diimplementasikan di Perguruan Tinggi Keagamaan Islam (PTKI). Integrasi ilmu pada dasarnya tengah diupayakan di berbagai wilayah (Lukman, 2017), termasuk implementasi integrasi ilmu hadis (Afwadzi, 2017), di mana hal ini terus diupayakan dalam kurikulum ilmu hadis (Suryadilaga, 2015).

\section{Kesimpulan}

Syarah hadis pendekatan kontemporer telah berlangsung dalam penelitian skripsi jenjang sarjana, tesis jenjang magister, dan disertasi jenjang doktor. Arah kebijakan pengembangan penelitian kontemporer interdisipliner, multidisipliner dan transdisipliner ditetapkan sejalan dengan implementasi mandat integrasi ilmu di PTKI. Keberlangsungan penelitian syarah hadis pada gilirannya telah menegaskan urgensi syarah hadis, signifikansi penyusunan proposal metode syarah hadis, pencarian model penelitian syarah hadis pendekatan kontemporer interdisipliner, multidisipliner, dan transdisipliner, dan mendesaknya penyusunan panduan penelitian syarah hadis kontemporer untuk skripsi, tesis, dan disertasi. Penelitian ini diharapkan memiliki implikasi manfaat bagi akademisi peminat penelitian syarah hadis. Keterbatasan penelitian ini sebatas tinjauan awal sehingga diperlukan penelitian lebih lanjut bagi penyusunan panduan skripsi, tesis, dan disertasi. Penelitian ini merekomendasikan penyusunan panduan penelitian syarah hadis kontemporer sejalan dengan mandat integrasi ilmu di PTKI.

\section{Daftar Pustaka}

Ad., E. S. (2005). Ilmu Hadits: Kajian Riwayah dan Dirayah. Bandung: Mimbar Pustaka.

Afwadzi, B. (2016). Membangun Integrasi Ilmu-Ilmu Sosial dan Hadis Nabi. Jurnal Living Hadis, 1(1), 101-128.

Afwadzi, B. (2017). Integrasi ilmu-ilmu alam dan ilmu-ilmu sosial dengan pemahaman hadis Nabi: Telaah atas konsepsi, aplikasi, dan implikasi. Theologia, 28(2), 351-390.

Amal, M. K. (2019). SK Penelitian Kolaboratif 2019.

Andariati, L. (2020). Hadis dan Sejarah Perkembangannya. Diroyah: Jurnal Studi Ilmu Hadis, 4(2).

Anshori, M. (2017). Syarh Hadis dari Masa Ke Masa. Jurnal Al-Irfani: Jurnal Kajian Tafsir Hadits, 3(1), 1-32.

Arifin, J. (2014). Pendekatan Ulama Hadis dan Ulama Fiqh dalam Menelaah Kontroversial Hadis. Jurnal Ushuluddin, 22(2), 145-154.

Bentley, P. J., Gulbrandsen, M., \& Kyvik, S. (2015). The relationship between basic and applied research in universities. Higher Education, 70(4), 689-709.

Burhanuddin, B. (2018). Metode dalam memahami Hadis. Jurnal Al-Mubarak: Jurnal Kajian Al-Qur'an Dan Tafsir, $3(1), 1-11$.

Cawelti, J. G. (1969). The concept of formula in the study of popular literature. Journal of Popular Culture, 3(3), 381.

Dadah, D. (2018). Metode Kritik Matan Hadis Misoginis Menurut Fatimah Mernissi. Diroyah: Jurnal Studi Ilmu Hadis, 3(1).

Dalil, F. Y. M. (2017). Hadis-Hadis tentang Farmasi; Sebuah Kajian Integratif dalam Memahami Hadis Rasulullah. PROCEEDING IAIN Batusangkar, 1(1), 309-326.

Darmalaksana, W. (2018). Manual Penulisan Proposal Penelitian Dasar Interdisipliner.

Darmalaksana, W. (2020a). Big Data, Pengetahuan Sistematis, dan Kecerdasan Kolektif: Studi Kasus Pembelajaran Metode Penelitian Hadis. Pre-Print Digital Library UIN Sunan Gunung Djati Bandung, 1.

Darmalaksana, W. (2020b). Cara Menulis Proposal Penelitian. Fakultas Ushuluddin UIN Sunan Gunung Djati Bandung.

Darmalaksana, W. (2020c). Formula Penelitian Pengalaman Kelas Menulis. Jurnal Kelas Menulis UIN Sunan Gunung Djati Bandung.

Darmalaksana, W. (2020d). Hasil dan Pembahasan untuk Artikel Konseptual. Jurnal Kelas Menulis Fakultas Ushuluddin, 1(5), 1-7.

Darmalaksana, W. (2020e). Metode Penelitian Kualitatif Studi Pustaka dan Studi Lapangan. Pre-Print Digital Library UIN Sunan Gunung Djati Bandung.

Darmalaksana, W. (2020f). Rencana Implementasi Penelitian Hadis pada Pendidikan Tinggi Indonesia: Sebuah Analisis Kebijakan. Jurnal Hadis Fakultas Ushuluddin UIN Sunan Gunung Djati Bandung.

Darmalaksana, W. (2020g). Sitasi Ilmiah Menggunakan Perangkat References pada Microsoft Word. Jurnal Kelas 
Menulis UIN Sunan Gunung Djati Bandung, 1.

Farida, U. (2020). Perkembangan Hadis Di Indonesia Pada Abad Ke-19 M: Telaah Terhadap Pemikiran Mahfuzh at-Tirmasi dalam Kitabnya Manhaj Dzawin-Nazhar. Riwayah: Jurnal Studi Hadis, 6(1), 141. https://doi.org/10.21043/riwayah.v6i1.6860

Firdaus, M. T., \& Suryadilaga, M. A. (2019). Integrasi Keilmuan Dalam Kritik Matan Hadis. TAJDID: Jurnal Ilmu Ushuluddin, 18(2), 153-176.

Hariono, D. (2019). Syarah Hadis: Model dan Aplikasi Metodologis. UNIVERSUM: Jurnal KeIslaman Dan Kebudayaan, 13(2).

Hosen, M., \& Musyafiq, A. (n.d.). Urgensi Integrasi Antara Ahli Figh dan Ahli Hadis dalam Memahami Sunah: Studi atas Pemikiran Syekh Muhammad al-Ghazali dalam Karyanya al-Sunah al-Nabawiyah baina Ahl al-Figh wa Ahl al-Hadis.

Hosen, M., \& Musyafiq, A. (2019). Urgensi Integrasi Antara Ahli Fiqh Dan Ahli Hadis Dalam Memahami Sunah: Studi atas Pemikiran Syekh Muhammad al-Ghazali dalam Karyanya al-Sunah al-Nabawiyah baina Ahl alFiqh wa Ahl al-Hadis. Riwayah: Jurnal Studi Hadis, 5(2), 205. https://doi.org/10.21043/riwayah.v5i2.4551

HS, M. A., \& Faizah, F. (2020). Syarah Hadis dalam Bentuk Film: Studi Syarah Hadis 'Keutamaan Salat Shubuh'dalam Film “Cinta Shubuh.” Dialogia: Jurnal Studi Islam Dan Sosial, 18(1), 126-145.

Jannah, D. (2017). Kritik dan Syarah Hadits. Al-Tarbawi Al-Haditsah: Jurnal Pendidikan Islam, 2(1).

Khaeruman, B. (2017). Perkembangan Hadis di Indonesia pada Abad XX. Diroyah: Jurnal Studi Ilmu Hadis, 1(2), $187-202$.

Kurniati, Y. (2020). Rekonstruksi Metodologi Keilmuan Syarah Hadis Klasik. Islam Transformatif: Journal of Islamic Studies, 4(1), 46-56.

Lukman, F. (2017). Integrasi-Interkoneksi dalam Studi Hadis Disertasi Di Uin Sunan Kalijaga Yogyakarta. RELIGIA, 1-11.

Muhtador, M. (2016). Sejarah Perkembangan Metode dan Pendekatan Syarah Hadis. Riwayah, 2(2), $259-272$.

Muin, M. (2015). Pemahaman Komprehensif Hadis Melalui Asbab Al-Wurud. Addin, 7(2).

Mujtaba, S. (2015). Studi Islam Interdisipliner: Sebuah Keniscayaan. AT-TURAS: Jurnal Studi Keislaman, 2(2).

Mulyadi, M. (2011). Penelitian kuantitatif dan kualitatif serta pemikiran dasar menggabungkannya. Jurnal Studi Komunikasi Dan Media, 15(1), 128-137.

Nugraha, M. T. (2020). Integrasi Ilmu dan Agama: Praktik Islamisasi Ilmu Pengetahuan Umum di Perguruan Tinggi. Al-Hikmah: Jurnal Agama Dan Ilmu Pengetahuan, 17(1), 29-37.

Nurgiyantoro, B., \& Gunawan, M. (2004). Statistik terapan untuk penelitian ilmu-ilmu sosial. Cetakan Ketiga (Revisi), PT Gramedia Pustaka Utama, Jakarta.

Prsetyo, B., \& Jannah, L. M. (2019). Metode penelitian kuantitatif.

Qomarullah, M. (2020). Metode Syarah Hadis dalam Kitab Al-Muntaqa Syarah al-Muwatta'. Khabar, 2(1), 85-99.

Raharusun, A. S. (2016). Tasawuf Nabawi: Membaca Maqom Rido Dalam Hadis Nabi. Syifa Al-Qulub, 1(1), 99-112.

Rodliyana, M. D. (2012). Hegemoni Fiqh Terhadap Penulisan Kitab Hadith. JOURNAL OF QUR'AN AND HADITH STUDIES, 1(1), 119-144.

Rohmatika, R. V. (2019). Pendekatan Interdisipliner dan Multidisipliner Dalam Studi Islam. Al-Adyan: Jurnal Studi Lintas Agama, 14(1), 115-132.

Sagir, A. (2017). Perkembangan Syarah Hadis dalam Tradisi Keilmuan Islam. Jurnal Ilmiah Ilmu Ushuluddin, 9(2), 129-151.

Saifuddin, S., Dzikri, N., \& Noor'ainah, N. (2015). Kecenderungan Syarah Hadis di Kalimantan Selatan (Telaah Literatur Syarah Hadis Terpublikasi Karya Ulama Banjar).

Santosa, S. (2016). Melacak Jejak Pensyarahan Kitab Hadis. Diroyah: Jurnal Ilmu Hadis, 1(1).

Sherman, R. R., \& Webb, R. B. (1988). Qualitative research in education: Focus and methods (Vol. 3). Psychology Press.

Soetari, E. (2015). Syarah dan Kritik Hadis dengan Metode Tahrij: Teori dan Aplikasi (2nd ed.). Bandung: Yayasan Amal Bakti Gombong Layang.

Sudikan, S. Y. (2015). Pendekatan interdisipliner, multidisipliner, dan transdisipliner dalam studi sastra. Paramasastra, 2(1).

Sulaemang, S. L. (2016). Teknik Interpretasi Hadis dalam Kitab Syarah Al-Hadis. Jurnal Ilmiah Ilmu Ushuluddin, 14(2), 125-132.

Sumarna, E. (2016). Syarah Hadis dalam Perspektif Kritik Dakhili dan Khariji (Menuju Pemaknaan Hadis yang Integritas). Jurnal Pendidikan Agama Islam-Ta'lim, 14(2), 157-164.

Suryadilaga, M. A. (2015). Ragam Studi Hadis di PTKIN Indonesia dan Karakteristiknya: Studi atas Kurikulum IAIN Bukittinggi, IAIN Batusangkar, UIN Sunan Kalijaga, dan IAIN Jember. Journal Of Qur'an And Hadith Studies, 4(2), 215-247.

Suryadilaga, M. A. (2017). Pembacaan Hadis dalam Perspektif Antropologi. Al Qalam, 34(2), 265-286.

Suwarjin, S. (2018). Kitab Syarah dan Tradisi Intelektual Pesantren. Jurnal Ilmiah Mizani: Wacana Hukum, Ekonomi 
Dan Keagamaan, 4(2), 85-98.

Taufik, E. T. (2020). Epistemologi Syarah Hadis di Perguruan Tinggi: Diskursus Genealogis Terhadap Transmisi dan Transformasi Metode Syarah Hadis di Indonesia. Ushuluna: Jurnal Ilmu Ushuluddin, 6(2), 33-50.

Tim Penyusun. (2018a). Keputusan Direktur Jenderal Pendidikan Islam Nomor 2500 Tahun 2018 tentang Standar Kompetensi Lulusan dan Capaian Pembelajaran Lulusan Program Studi Jenjang Sarjana pada PTKI. Jakarta.

Tim Penyusun. (2018b). Keputusan Direktur Jenderal Pendidikan Islam Nomor 6165 Tahun 2018 tentang Standar Kompetensi Lulusan dan Capaian Pembelajaran Lulusan Program Studi Jenjang Magister dan Doktor pada PTKI. Jakarta.

Tim Penyusun. (2018c). Keputusan Direktur Jenderal Pendidikan Islam Nomor 6994 Tahun 2018 tentang Agenda Riset Keagamaan Nasional (Arkan) 2018-2028. Jakarta.

Tim Penyusun. (2019). Keputusan Direktur Jenderal Pendidikan Islam Nomor 2498 Tahun 2019 tentang Pedoman Implementasi Integrasi Ilmu di PTKI. Jakarta.

Yusuf, A. M. (2016). Metode penelitian kuantitatif, kualitatif $\mathcal{E}$ penelitian gabungan. Prenada Media.

Zahrah, N. Siti. (2020). Gharib al-Hadits Sebagai Embriologi Syarah Hadits dan Transformasinya. El-Afkar: Jurnal Pemikiran Keislaman Dan Tafsir Hadis, 9(1), 127-141.

(C) 2020 by the authors. It was submitted for possible open access publication under the terms and conditions of the Creative Commons Attribution (CC BY SA) license (https://creativecommons.org/licenses/by-sa/3.0/). 